\title{
ANATOMICAL AND PHYSICAL PROPERTIES OF BISBUL WOOD (Diospyros blancoi A.DC.)
}

\author{
Krisdianto and Abdurachman ${ }^{1}$
}

\begin{abstract}
Ebony (Diospyros sp.) is a heavy hardwood that is popularly known as blackwood. Diospyros consists of over 300 species spread throughout tropics area and about 100 species occur in Indonesia. Bisbul wood (Diospyros blancoi A.DC.) is one species of streaked ebony that is locally known as 'buah mentega'. The anatomical and physical properties of bisbul were studied to collect information for wood identification and to support appropriate use of the timber. Anatomical properties were studied from microtome sectioned samples, which have been coloured by safranin and mounted by entellan, while fiber dimensions were studied from macerated samples. Physical properties of bisbul wood studied include moisture content, density and percentage of volumetric shrinkage. Moisture content and density were studied from $20 \times 20 \times 20 \mathrm{~mm}$ samples based on wet and oven dry condition. Volumetric shrinkage was measured from dimension changes in radial, tangential and longitudinal shrinkage of $20 \times 20 \times 40 \mathrm{~mm}$ samples. The samples were measured in wet and oven dry conditions. The main anatomical characteristics to identify bisbul wood were black wood with pinkish streaked, heavy and very hard, very fine texture, even, lustrous surface and glossy, distinct growth ring, small size of vessels, apotracheal parenchyma forming reticulate pattern. The average moisture content was $59.86 \pm$ $2.84 \%$, the density average was $0.74 \pm 0.04 \mathrm{gr} / \mathrm{cm}^{3}$ and volumetric shrinkage was $10.41 \pm 0.70 \%$. The higher the stem, the more moisture content and the lower the density will be. Sapwood density was lower and had more moisture content than heartwood. The black pinkish heavy wood, bisbul was recommended to be used for carvings, sculpture, souvenir and luxury interior products.
\end{abstract}

Keywords: Diospyros blancoi, bisbul, anatomy, physical

\section{INTRODUCTION}

Lesser natural timber sources have driven to lack of timber as raw material in wooden based industries. In this condition, Indonesian government suggests to obtain raw material either from plantation forest or utilizing lesser known wood species. Information and data of lesser-known species are important for wood identification and to support its appropriate utilization.

Ebony wood, which is popularly known as black wood, is a group of wood from Diospyros sp. that belongs to Ebenaceae family. Soerianegara (1995) classified Diospyros sp. wood into three groups: Black Ebony, Streaked Ebony and White Diospyros. Diospyros sp. consists of 300 species and spreads throughout tropical areas. Among them, it is about 100 species grow in Indonesia. The most famous ebony wood is black ebony (Diospyros celebica Bakh.) that grows in Sulawesi (Soerianegara, 1995).

${ }^{1}$ Forest Products Technology Research and Development Center, Bogor 
Bisbul (D. blancoi A.DC.) is one of streaked ebony species that grow in Sumatera and West Java. In Sumatera, the tree is locally known as 'buah mentega' because of its edible fruit. While in West Java, it is known as bisbul or mabolo. The tree is often planted for its sweet edible fruit and also for a roadside tree (Soerianegara, 1995). The purpose of this study was to determine the anatomical properties, fiber dimensions as well as physical properties of bisbul wood. The information of anatomical and physical properties were collected to support the appropriate use of bisbul.

\section{MATERIAL AND METHOD}

\section{A. Material}

Bisbul tree sample was taken from roadside of Ciapus area, Bogor, West Java. Wood samples were taken from three height: bottom, medium and top of the log. In each height, samples were taken from three parts: sapwood, heartwood and pith. The sampling scheme is clearly shown in Figure 1.
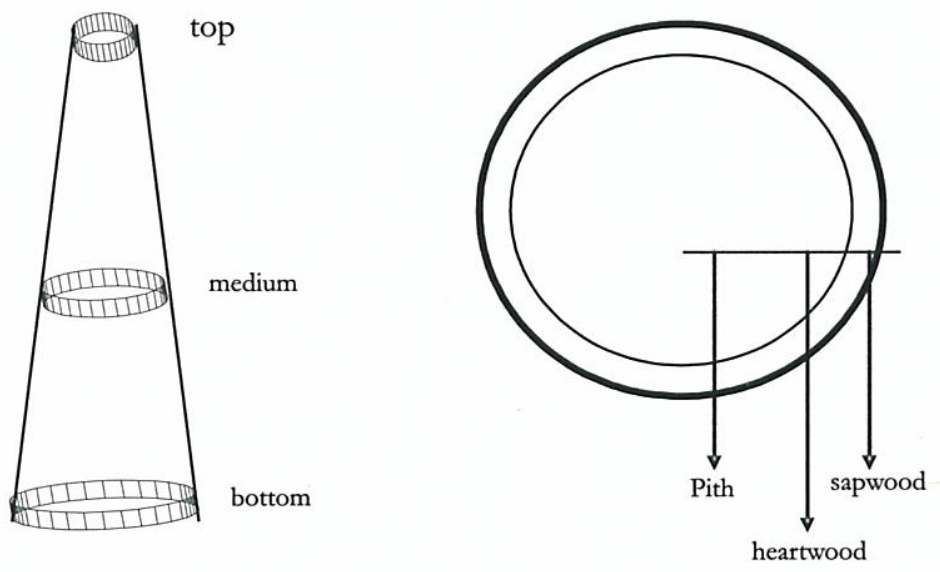

Figure 1. Sampling from one log 


\section{B. Methods}

\section{Anatomical Properties}

Sample blocks were prepared using sample preparation method reported by Fujii (1989). Tree block sections from heartwood were each assigned for examination of anatomical features on consecutively cross-sectional (transverse), radial and tangential surfaces. The block of samples specimen were first air-dried and then soaked in distilled water for about one week. After saturated, the samples were then transferred into a container containing solution of alcohol-glycerin 1:1 and further kept for about one week before sectioning.

The observed characters with respect to the anatomical features based on IAWA Committee list (Wheeler et al., 1989). Some of the features were quantitative data. The quantitative data in this study was a representation of first performing 30 measurements on certain feature of each investigated sample, and then taking average of them. The quantitative features includes vessels (diameter, length, frequency per sq. cm), ray (height, frequency per $\mathrm{mm}$ ) and fibers (length, diameter, wall thickness).

The quantitative data of fibers dimension and vessels length were measured from macerated samples. In this regard, the associated wood samples were macerated which was conducted based on Schultze methods (Sass, 1960). The sample material was heated slowly at $40-60^{\circ} \mathrm{C}$ in the mix of concentrated nitric acid and hydrogen peroxide at the ratio of $1: 1$. The heating took about 12 hours to produce adequately macerated material or a satisfactory separation of wood fibers for further dimensional examinations.

\section{Physical Properties}

Wood physical properties studied were moisture content, density and volumetric shrinkage. Moisture content was the amount of moisture in a given piece of wood. It was expressed by percentage of water weight in wood material from the wood substance without water. The amount of water-free solid substances present in wood were obtained by drying the wood in the oven at $103 \pm 2{ }^{\circ} \mathrm{C}$ to constant weight. The weight of water presents in wood was obtained from the difference in weights before and after drying. The moisture content was clearly stated as:

$$
M C=\frac{M_{1}-M_{o}}{M_{o}} \times 100 \%
$$

Where, $M C=$ moisture content $(\%)$

$M_{0}=$ oven-dry weight (gr)

$M_{1}$ = weight of wood with moisture/before oven-dry (gr) 
Density of the wood was the most commonly quoted wood property. It correlated with general characteristics as well as physical and mechanical properties (Dadswell, 1972). In this study, wood density was expressed in air-dry density. Wood was air dried to about $15 \%$ moisture content and density was expressed as mass of air-dried material (gr) divided by air-dried volume $\left(\mathrm{cm}^{3}\right)$.

Volumetric shrinkage was formulated as percentage of wood shrinkage in tangential, radial and longitudinal directions. The three wood directions were measured on $20 \times 20 \times 40$ $\mathrm{mm}$ wood samples in fresh condition as initial volume. After oven-dried, moisture had removed from wood samples and final volume was measured. The volumetric shrinkage was expressed as percentage of volumetric reduction of wood from initial volume.

\section{RESULT AND DISCUSSION}

\section{A. Tree Morphology}

Bisbul wood which is popularly known as 'buah mentega' in Sumatera and 'mabolo' in West Java belongs to Ebenaceae family. It was previously known as $D$. discolor Willd. The picture of bisbul tree, its bark and fruit are shown in Figure 1.

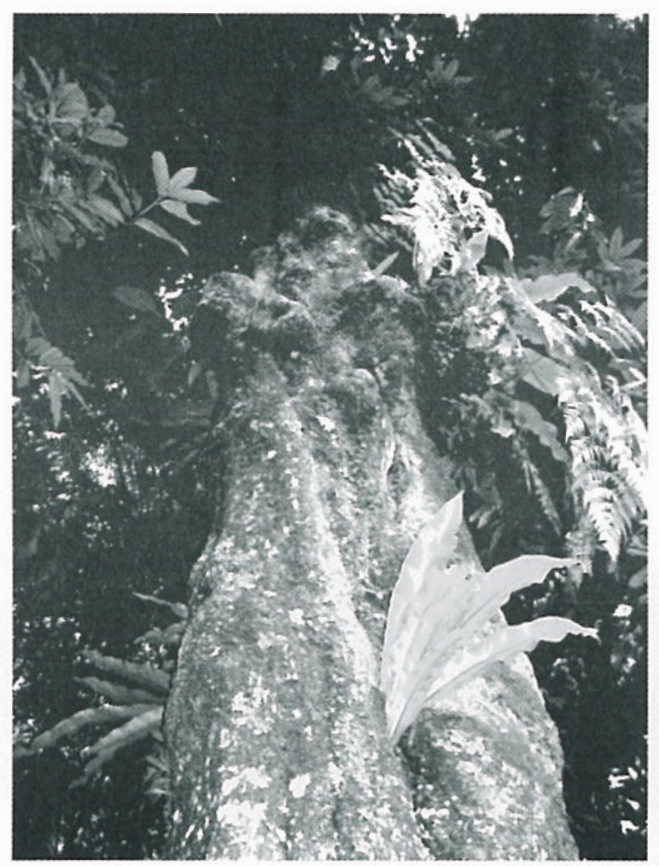

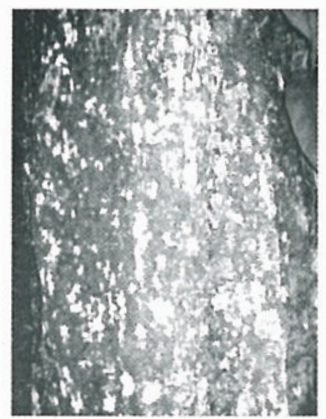

a

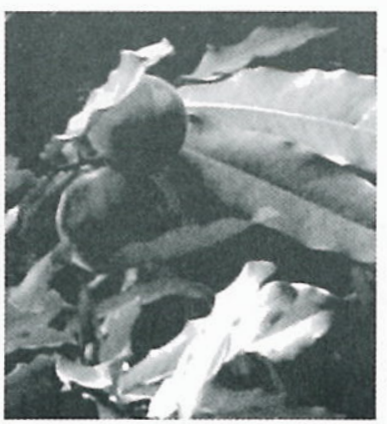

$\mathrm{b}$

Figure 1. Standing tree of bisbul (D. blancoi A.DC.)

Remarks: a. Bark

b. Leaf and fruit 
Bisbul tree is medium sized tree up to 15 - $32 \mathrm{~m}$ tall, bole branchless for up to $10 \mathrm{~m}$, generally straight and fluted (Soerianegara, 1995). The tree is found in both primary and secondary forest up to $800 \mathrm{~m}$ altitude.

\section{B. Wood Anatomy}

\section{General characteristics}

Colour : heartwood black with pinkish streaked. Figure : flat sawn board fine and lustrous. Texture: fine. Grain: straight to shallowly interlock. Hardness: wood is hard.

\section{Anatomical properties}

Growth rings distinct marked by flattened fibers. Vessels diffuse, solitary and radial multiples of 28 , small size $114.44 \pm 19.16 \mu \mathrm{m}$ in tangential diameter; length $161.14 \pm$ $21.3 \mu \mathrm{m}$, perforations simple; intervessel pits non-vestured, alternate, fine $5.8 \pm 0.39 \mu \mathrm{m}$ in diameter; vessel-ray and vessel parenchyma pits are similar in type and size to intervessel pits; vessels are filled or coated with dark coloured substances; tyloses often present. Parenchyma scanty paratracheal and abundant apotracheal, reticulate, in bands 1 - 2 cells wide, often seemingly in long concentric bands; in 68 celled strands. Rays $17 \pm 1.7$ per $\mathrm{mm}$, uniseriate. Prismatic crystals present scarce in ray cells and scarce to fairly numerous in chambered axial parenchyma cells. Silica bodies absent. Fibers $1193 \pm 24.5 \mu \mathrm{m}$ in length; fiber diameter $42.2 \pm 1.4 \mu \mathrm{m}$; lumen diameter $32 \pm 1.4 \mu \mathrm{m}$ and fiber pits $3.38 \pm 0.43 \mu \mathrm{m}$ in diameter.

The main anatomical characteristics to identify bisbul wood are its black colour with pinkish streaky black wood. The wood is relatively heavy and very hard. Its texture is very fine and even, lustrous surface and glossy. Growth ring is distinct, vessels are small, apotracheal parenchyma forming reticulate pattern. The transverse, radial and tangential surfaces of bisbul are shown in Figure 2. 


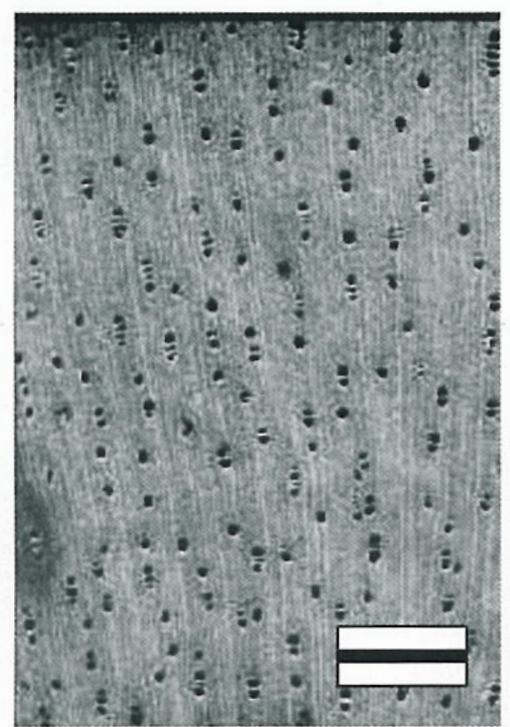

a

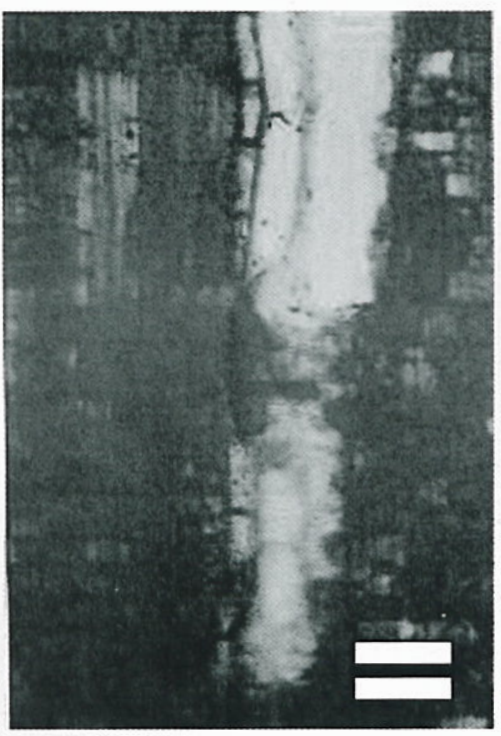

c

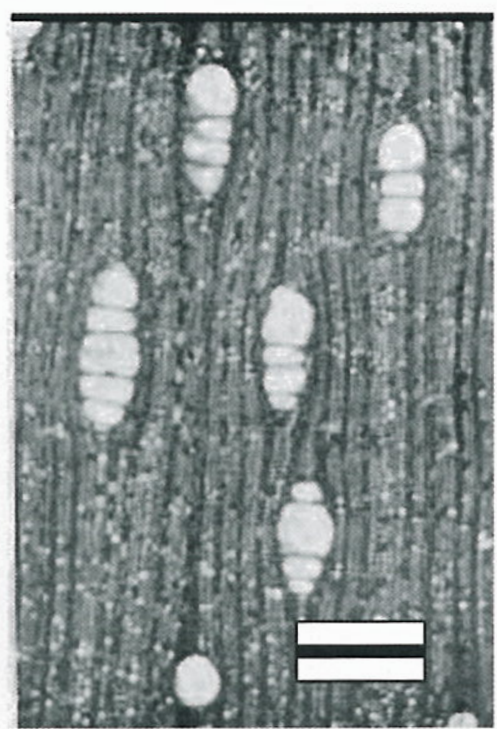

$\mathrm{b}$

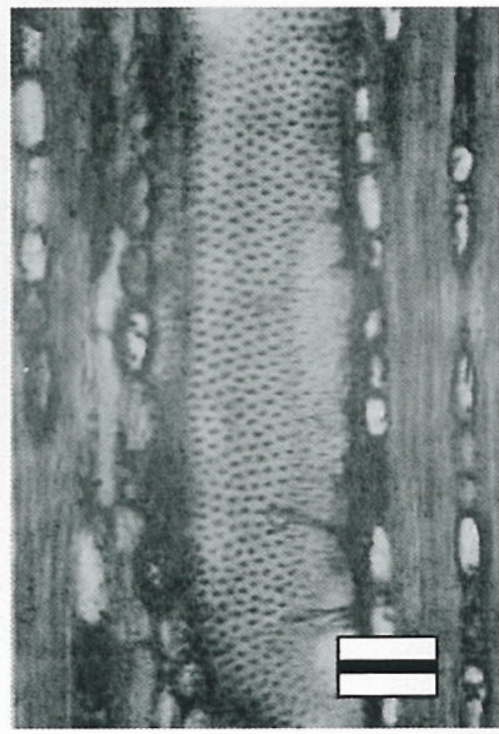

d

Figure 2. Wood anatomical structure of Bisbul (D. Blancoi A.DC.)

a. Transverse surface, scale bar $=1 \mathrm{~mm}$

b. Transverse surface, scale bar $=200 \mu \mathrm{m}$

c. Radial surface, scale bar $=80 \mu \mathrm{m}$

d. Tangential surface, scale bar $=40 \mu \mathrm{m}$ 


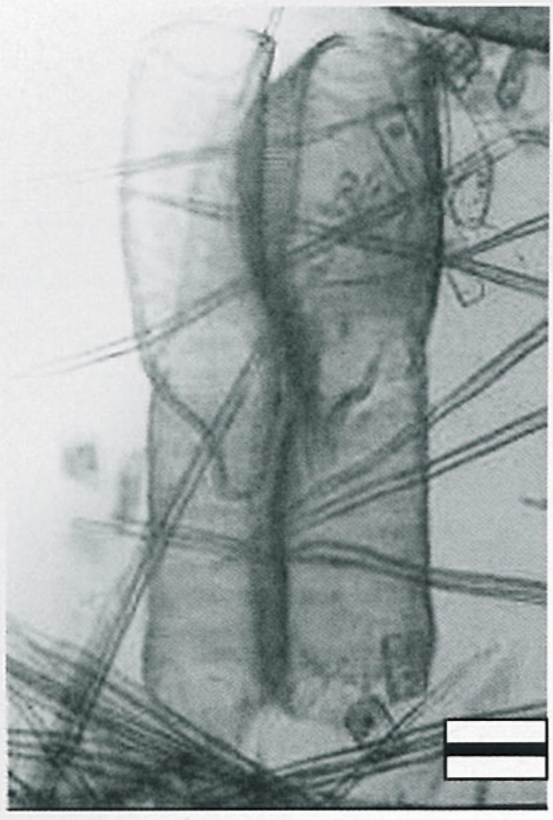

Figure 3. Vessels shown in macerated samples, scale bar $80 \mu \mathrm{m}$

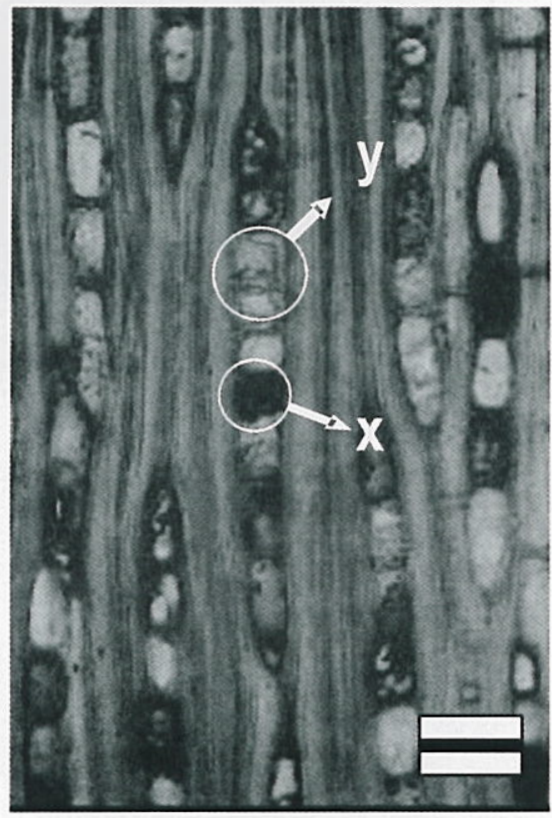

Figure 4. Black deposit (x) and prismatic crystals (y), scale bar $40 \mu \mathrm{m}$

In general, Diospyros wood has been clearly described by Kartasujana (1981) and Sudo (1995). Kartasujana stated that there are another Diospyros species grow in Indonesia, but D. celebica is the only species named real eboni. While, Sudo (1995) classified Diospyros wood into three groups: black ebony, streaked ebony and white Diospyros. D. blancoi wood is classified in streaked ebony. It is named as streaked ebony because its pinkish streaked wood.

The difference of bisbul wood to other Diospyros wood is the ray that is uniseriate. The ray of $D$. ferrea wood is 1-2 seriate, while D. papuana is 1-3 seriate (Sudo, 1995). The uniseriate ray is also found in D. ebenum, however, the wood is black without streaked. As a result, the typical characteristics of $D$. blancoi wood is the pinkish streaked and uniseriate rays.

\section{Physical Properties}

\section{Moisture Content}

The amount of moisture in a given piece of wood is known as moisture content. It is expressed by percentage of water weight in wood material from the wood substance without water. The moisture content of bisbul wood taken from different part of tree is shown in Figure 5. 


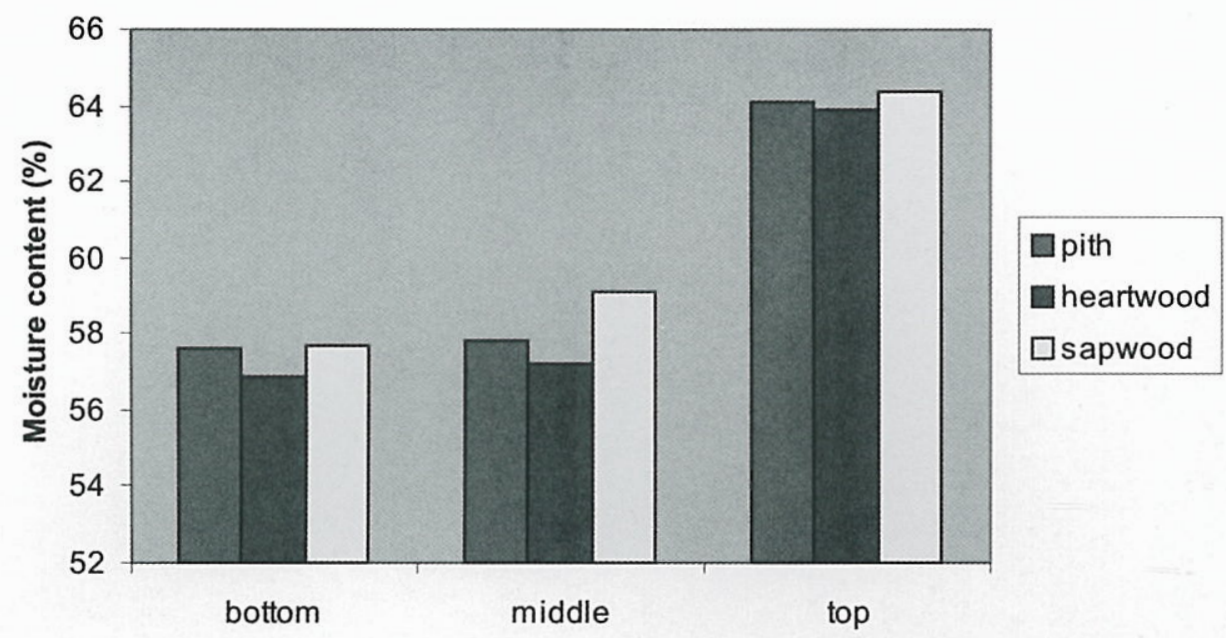

Figure 5. Histogram of moisture content in different position of one bisbul log

In average, the moisture content of bisbul wood is $59.86 \pm 2.84 \%$. Samples with the highest moisture content are samples taken from top part, while the lowest are samples taken from bottom part. In every height, samples taken from sapwood have the highest moisture content, while heartwood content less moisture than pith and sapwood in every height.

\section{Density}

Density is the single parameter that correlates with general characteristics as well as physical and mechanical properties (Dadswell, 1972). Density of bisbul wood is shown in Figure 6. 


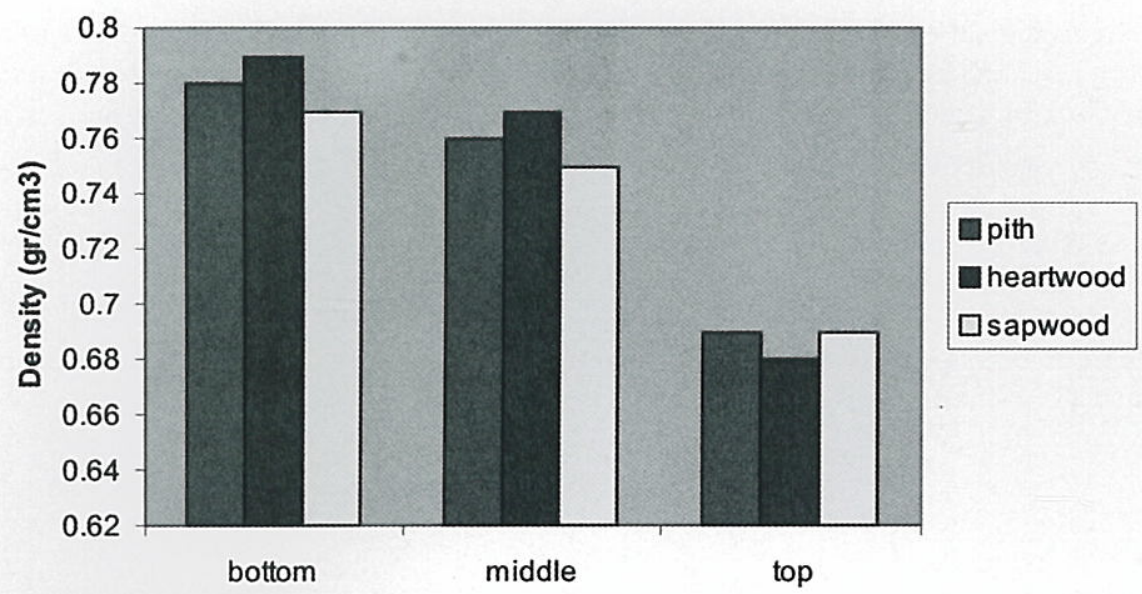

Figure 6. Histogram of wood density in different position of one bisbul log

In average, the bisbul wood density is $0.74 \pm 0.04 \mathrm{gr} / \mathrm{cm}^{3}$. The highest density of bisbul wood is taken from bottom, followed by middle part, while the lowest density is wood sample taken from the top. In other words, the higher the sample, the lower density of bisbul wood. In bottom and middle height, the density of heartwood is higher than pith and sapwood except for samples from the top of the tree.

\section{Shrinkage}

Shrinkage is volumetric reduction of wood samples during drying. The percentage shrinkage of bisbul wood samples taken from different part of log is shown in Figure 7.

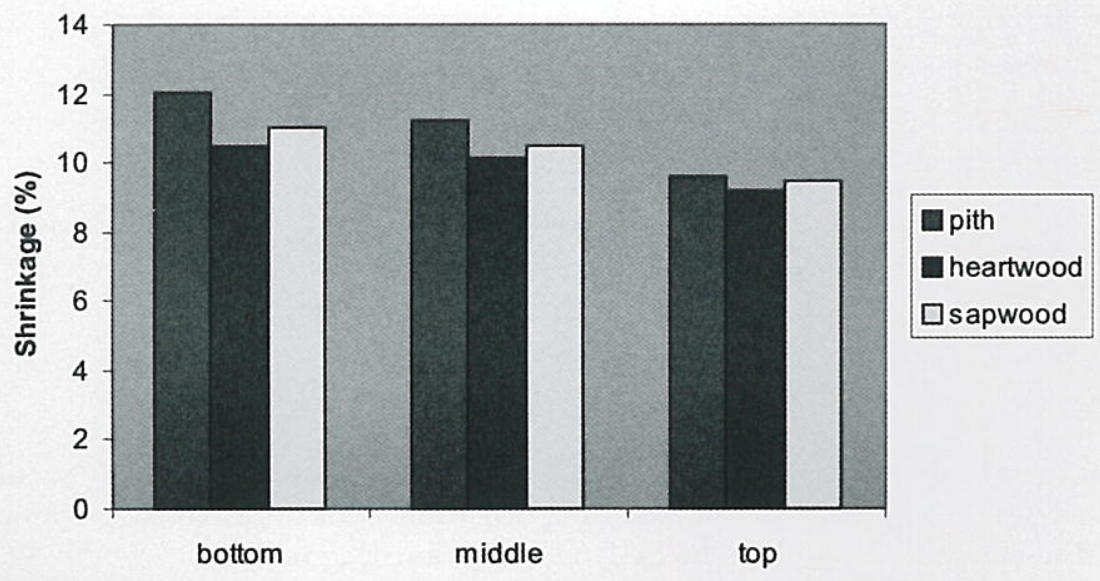

Figure 7. Histogram of volumetric shrinkage in different position of one bisbul log 
In average, the volumetric shrinkage of bisbul wood from wet to oven dry condition is $10.41 \pm 0.70 \%$. The percentage of volumetric shrinkage varies between different part of a bisbul log. In general, samples taken from bottom log have the highest percentage of volumetric shrinkage, while heartwood of bisbul wood acquired the lowest volumetric shrinkage.

Generally, bisbul wood is suitable for furniture and construction wood products, because its density is relatively high and its volumetric shrinkage moderately low. However, because of black pinkish streaked colour of wood and lustrous surface, its timber was utilized for luxury products, such as carvings, sculpture, souvenirs and luxurious interior products. Locally, the timber is traded together with black ebony (D. celebica Bakh.).

\section{CONCLUSION}

1. The main anatomical characteristic to identify bisbul wood are black wood with pinkish streak, heavy and very hard, very fine texture, even, lustrous surface and glossy, distinct growth ring, small vessels, apotracheal parenchyma forming reticulate pattern.

2. The average of moisture content is $59.86 \pm 2.84 \%$, density average is $0.74 \pm 0.04$ $\mathrm{gr} / \mathrm{cm}^{3}$ and volumetric shrinkage average is $10.41 \pm 0.70 \%$.

3. Along the stem height, the higher wood sample tested, the more moisture content and the lower the density will be.

4. In general, sapwood has lower density and more moisture content than heartwood.

5. Bisbul wood is recommended for luxurious products, such as carvings, sculpture, souvenirs and luxurious interior products.

\section{REFERENCES}

Dadswell, H.E. 1972. The anatomy of Eucalyptus woods. Technological paper No. 66. Commonwealth Scientific and Industrial Research Organization (CSIRO), Division of Forest Products, Melbourne.

Fujii, T. 1989. Vessel characters of Sophora group (Leguminosae). Proceeding Wood Anatomy Conference, FPRDI, Philippines. pp.135-150.

Kartasujana, I. 1981. Sifat anatomi kayu Eboni In Martawijaya, A., I. Kartasujana, K. Kadir and S.A. Prawira (Eds.). Atlas Kayu Indonesia, $1^{\text {st }}$ edition. Badan Litbang Kehutanan, Bogor.

Sass, J.E. 1960. Botanical Microtechnique. The IOWA State University Press, Ames, IOWA. p.228.

Soerianegara, I. 1995. General part of Diospyros L. In Lemmens, R.H.M.J., I. Soerianegara and W.C.Wong (Eds.). Plant Resources of South East Asia No.5(2). Timber trees: Minor commercial timbers. PROSEA Foundation, Bogor. P.185. 
Sudo, S. 1995. Anatomical properties of Diospyros L. In Lemmens, R.H.M.J., I. Soerianegara and W.C.Wong (Eds.). Plant Resources of South East Asia No.5(2). Timber trees: Minor commercial timbers. PROSEA Foundation, Bogor. p.186 - 187.

Wheeler, E.A., P. Baas and P. Gason. 1989. IAWA list of microscopic features for hardwood identification. IAWA Bulletin 10(3):219-332. 